\title{
MISKONSEPSI DAN MISPERSEPSI \\ DALAM KOMUNIKASI \\ DI SEKTOR PUBLIK \\ Dinamika Penyusunan Peraturan Daerah di Kabupaten Tasikmalaya
}

\section{Satya Laksana}

satya_laksana@yaboo.com

Pejabat Fungsional Perencana Muda di Bappeda Kabupaten Tasikmalaya, Jawa Barat

\section{ABSTRAK}

Misconceptions and misperceptions that occur in the public sector on a legal object is a phenomenon that can magnify the difficulty of implementing the regulation. This paper elaborates on misperceptions and misconceptions in public communication within the case study in the process of drafting the Regional Regulations (Perda) on the Protection of Sustainable Agricultural Land (LP2B) in Tasikmalaya District, West Java Province. By using descriptive methods this paper describes the dynamics of communication among stakeholders which are fulfilled with discourse, controversy, and egosectoral regarding the protection of $\angle P 2 B$ in the period 2014-2019. Furthermore, this paper synthesizes the writer's own conceptions and arguments to correct the misperceptions and misconceptions based on academic references and relevant statutory arguments. The importance of this paper is for problem mapping and problem-solving of the complexity of LP2B protection in order to minimize discourse in public communication regarding LP2B. Policy implications are discussed.

Perbedaan atau kesalahan konsep (miskonsepsi) dan perbedaan atau kesalahan persepsi (mispersepsi) yang terjadi pada sektor publik (instansi pemerintah) mengenai sebuah objek hukum merupakan sebuah fenomena yang dapat menambah sulitnya implementasi sebuah peraturan perundang-undangan. Artikel ini mengelaborasi mispersepsi dan miskonsepsi dalam komunikasi publik dengan studi kasus pada proses penyusunan Peraturan Daerah (Perda) tentang perlindungan Lahan Pertanian Pangan Berkelanjutan (LP2B) di Kabupaten Tasikmalaya, Provinsi Jawa Barat. Dengan menggunakan metode deskriptif, artikel ini menggambarkan dinamika komunikasi di antara pemangku kepentingan (stakeholder) yang sarat dengan diskursus, kontroversi, dan ego-sektoral mengenai perlindungan LP2B dalam kurun waktu 2014-2019. Artikel ini mensintesis konsepsi dan argumentasi penulis sendiri untuk meluruskan mispersepsi dan miskonsepi yang terjadi berdasarkan referensi ilmiah dan argumen hukum yang relevan. Diharapkan artikel ini bermanfaat dalam memetakan masalah dan menguraikan kerumitan perlindungan LP2B sehingga dapat meminimalkan diskursus dalam komunikasi di sektor publik. Implikasi kebijakan sebagai rekomendasi disampaikan di akhir artikel.

Kata kunci: Mispersepsi, Miskonsepsi, Laban Pertanian Pangan Berkelanjutan (LP2B), Peraturan Daerah, Tata ruang

\section{PENDAHULUAN}

Salah satu kaidah pembangunan berkelanjutan adalah keberlanjutan politik (political sustainability) yang dicirikan dengan adanya penghormatan terhadap hak asasi manusia, demokrasi, serta kepastian kesediaan pangan, air dan pemukiman (Djajadiningrat, 1992; Pearce and Warford, 1993). Khusus dalam hal keberlanjutan penyediaan pangan, Indonesia menetapkan UndangUndang Nomor 41 Tahun 2009 tentang Lahan Pertanian Pangan Berkelanjutan (selanjutnya disebut UU LP2B). Implementasi UU LP2B ini secara yuridis diterjemahkan ke dalam empat Peraturan Pemerintah (PP) dan Peraturan Menteri Pertanian
(Permentan).

Di tingkat daerah, sejumlah pemerintah daerah telah meratifikasi UU LP2B ke dalam peraturan daerah (perda). Misalnya Provinsi Jawa Barat menetapkan Perda Nomor 27 tahun 2010 dan Kabupaten Tasikmalaya menetapkan Perda Nomor 4 Tahun 2016 tentang hal yang sama, yaitu Perlindungan LP2B. Dalam proses penyusunan Perda LP2B ini ditemukan banyak kendala dan kesulitan yang diakibatkan oleh perbedaan persepsi (mispersepsi) dan perbedaan konsep (miskonsepsi) di antara stakebolder atau birokrat, baik di tingkat pusat maupun daerah. Kesulitan ini tidak sertamerta berakhir seketika Perda LP2B dan perda lain 
yang terkait ditetapkan, namun terus berlanjut ke dalam tataran teknis implementasi dan dalam diskusi di forum koordinasi lintas-institusi, baik vertikal maupun horizontal.

Tulisan ini mencoba mengelaborasi mispersepsi dan miskonsepsi para stakebolder mengenai perlindungan LP2B dengan studi kasus di Kabupaten Tasikmalaya dalam kurun waktu 20142019. Untuk memperkaya referensi, penulis juga menyinggung pengaturan LP2B di daerah lain sebagai komparasi. Selanjutnya penulis memaparkan konsepsi dan persepsi penulis sendiri mengenai topik permasalahan yang dibahas berdasarkan referensi ilmiah dan argumen hukum yang relevan untuk menjawab mispersepsi tersebut.

Pembahasan masalah dan kesimpulan artikel ini disintesis dari catatan penulis dalam mengikuti proses penyusunan perda di Kabupaten Tasikmalaya yang ditulis dengan seobjektif mungkin walaupun bersifat opini personal sehingga terbuka untuk koreksi atau diskusi lebih lanjut. Meskipun ruang lingkup artikel ini terbatas pada isu atau permasalahan yang berkembang di Kabupaten Tasikmalaya, diharapkan rekomendasi kebijakan yang ditawarkan dapat kontekstual bagi daerah lain dan dapat dikembangkan untuk skala provinsi dan nasional.

\section{METODE}

Metode yang digunakan dalam artikel ini adalah metode deskripsi kualitatif yang disintesis dari catatan penulis dalam proses penyusunan peraturan daerah yang berkaitan dengan perlindungan LP2B. Tujuan artikel ini adalah menggambarkan kesulitan perlindungan LP2B karena miskonsepsi dan mispersepsi di kalangan birokrasi pusat dan daerah yang terjadi pada tiga aspek, yaitu (1) aspek kepemilikan lahan, (2) aspek proses penetapan, dan (3) aspek implementasi perlindungan LP2B.

Disusun secara kronologis dan tematis, artikel ini menyajikan elaborasi upaya perlindungan lahan pertanian pangan secara berkelanjutan melalui instrumen Perda LP2B dan Perda mengenai Tata Ruang baik umum (Rencana Tata Ruang Wilayah /RTRW) maupun rinci (Rencana Detail Tata Ruang/RDTR perkotaan dan kawasan strategis) di Kabupaten Tasikmalaya. Selain itu, artikel ini juga mensintesis catatan penulis dalam forum rapat koordinasi lintas-institusi mengenai LP2B di tingkat provinsi dan nasional dalam kurun waktu 2014-2019. Sintesis dari catatan penulis digunakan untuk menjawab topik utama artikel, yaitu mengapa sulit melindungi lahan pertanian secara berkelanjutan?

\section{HASIL DAN PEMBAHASAN}

\section{Permasalahan}

Permasalahan yang dibahas adalah mispersepsi dan miskonsepsi di kalangan stakeholder mengenai perlindungan LP2B. Dalam Kamus Besar Bahasa Indonesia, miskonsepsi berarti salah pengertian atau salah paham, sedangkan mispersepsi bermakna salah penanggapan atau salah penerimaan. Artikel ini menggunakan kedua istilah ini secara bersamaan atau saling bergantian (interchangeable) untuk menggambarkan perbedaan (atau kekeliruan) pendapat di antara para stakeholder dalam membahas perlindungan LP2B.

Stakeholder yang dimaksud dalam artikel ini adalah pemangku kepentingan, yaitu instansi lingkup pertanian di Kabupaten Tasikmalaya, Provinsi Jawa Barat, dan Kementerian Pertanian; serta instansi lain yang terkait LP2B meliputi Bappeda, Dinas Tata Ruang, dan Kementerian Tata Ruang/ Badan Pertanahan Nasional, yang diwakili oleh pejabat, birokrat, atau personel yang bersamasama penulis pernah menghadiri rapat koordinasi, diseminasi, workshop, focus group discussion dan forum sejenis yang membahas LP2B dan/atau topik lain yang berkaitan.

Mispersepsi dan miskonsepsi yang dibahas meliputi aspek kepemilikan lahan, proses penetapan LP2B, dan implementasi perlindungan LP2B. Sebagai upaya menerapkan kaidah atau prinsip hipotesis deskriptif, untuk sementara istilah "mispersepsi" diganti menjadi "persepsi", dan istilah "miskonsepsi" diganti menjadi "konsepsi" sebelum kemudian diuji atau dibuktikan di dalam pembahasan bahwa konsepsi dan persepsi tersebut keliru (miss).

\section{Persepsi Mengenai Kepemilikan Lahan}

Persepsi yang berkembang di kalangan stakeholder mengenai isu kepemilikan lahan di antaranya adalah pendapat bahwa pencegahan alih fungsi lahan pertanian melalui penetapan LP2B hanya bisa efektif sepenuhnya bila lahan pertanian dimiliki atau dibebaskan oleh pemerintah. Persepsi ini menyiratkan pesimisme terhadap kapabilitas pemerintah dalam hal pengaturan alih fungsi lahan pertanian yang notabene adalah hak milik perorangan. Adagium di masyarakat dalam bahasa Sunda yang mengatakan "sawab derwek, kumaha 
dewek" yang berarti: "sawah saya terserah saya mau digunakan untuk apa" sering dilontarkan dalam rapat pembahasan LP2B oleh stakeholder, baik sebagai pendapat peserta rapat maupun prolog pimpinan rapat.

Persepsi ini dikonfirmasi oleh kebijakan beberapa pemerintah daerah, seperti Pemerintah Kota Bandung yang membeli sebidang lahan sawah di pinggiran kota di Kecamatan Cibiru yang kemudian ditetapkan sebagai lahan sawah abadi Kota Bandung. Kebijakan positif tersebut dicoba untuk ditiru oleh pemerintah daerah lainnya yang memiliki karakter serupa dengan Kota Bandung, seperti Kota Cimahi. Lebih jauh pemerintah Provinsi Jawa Barat mengidentifikasi apakah pemerintah kabupaten/kota di daerahnya melakukan kebijakan serupa dalam rangka evaluasi perlindungan LP2B di Jawa Barat. Tim dari Bidang Pertanian Biro Produksi Setda Provinsi Jawa Barat pada 2018 mengunjungi kabupaten/kota dengan menyebarkan kuesioner yang salah satu poinnya menanyakan apakah kabupaten/kota menerapkan kebijakan pembebasan lahan sawah dalam rangka perlindungan LP2B.

Pembebasan lahan sawah oleh pemerintah merupakan kebijakan positif untuk menunjukkan simbol keberpihakan pemerintah (daerah) terhadap ketahanan pangan dengan melestarikan lahan sawah sebagai "etalase pembangunan" sektor pertanian. Namun demikian, persepsi bahwa pencegahan alih fungsi sawah atau perlindungan LP2B hanya efektif bila dilakukan dengan pembebasan lahan oleh pemerintah tidak menawarkan solusi yang rasional. Kalkulasi statistik jumlah total kebutuhan pangan nasional dikonversikan menjadi luas lahan yang dibutuhkan untuk produksi pangan dikaitkan dengan keberpihakan dan keterbatasan anggaran pemerintah menggambarkan betapa sulitnya (untuk tidak mengatakan mustahil) melindungi LP2B dengan mekanisme pembebasan lahan.

\section{Persepsi Mengenai Proses Penetapan LP2B}

Ada lima isu yang berkembang mengenai proses penetapan LP2B di kalangan stakeholder. Pertama adalah adanya kekaburan penetapan LP2B di dalam Perda. PP No. 1 tahun 2011 secara eksplisit mengatur bahwa LP2B kabupaten/kota ditetapkan dalam Rencana Tata Ruang kabupaten/kota. Beberapa pemerintah daerah menerbitkan pula Perda tentang LP2B secara khusus dengan cakupan pengaturan yang beragam. Sejumlah daerah hanya mengatur norma hukum perlindungan LP2B tanpa menetapkan lokasi LP2B secara spasial (seperti di
Provinsi Jawa Barat dan Kabupaten Tasikmalaya), sementara daerah lain menetapkan lokasi spasial (seperti Kabupaten Garut dan Kabupaten Temanggung). Perbedaan pengaturan ini menjadi diskursus tersendiri di lingkungan pemerintahan daerah.

Isu kedua adalah perbedaan persepsi apakah penetapan LP2B di kabupaten/kota harus mengikuti target luasan yang dikalkulasi oleh pemerintah provinsi ataukah pemerintah kabupaten/kota menetapkan sendiri luasan LP2B di wilayahnya. Penentuan target luasan LP2B di kabupaten/kota oleh pemerintah provinsi ini menggunakan analogi atau yurisprudensi pengaturan persentase kawasan lindung di kabupaten/kota di Jawa Barat dalam peraturan tata ruang agar memenuhi target persentase kawasan lindung provinsi. Wacana ini menggunakan kalkulasi ekonomi dengan indikator jumlah dan pertumbuhan penduduk, kebutuhan pangan pokok total se-provinsi, kemudian dikonversi menjadi luas lahan yang dibutuhkan untuk produksi pangan yang selanjutnya dibagi habis kepada daerah sesuai dengan potensi luas baku lahan yang ada di masing-masing kabupaten/kota. Wacana ini terus bergulir dalam berbagai forum disertai dengan pro-kontra tanpa menghasilkan kesimpulan akhir.

Isu ketiga adalah penetapan LP2B harus didahului dengan identifikasi lahan secara detail berupa identifikasi pemilik lahan lengkap (by name by address). Persepsi ini berkembang di kalangan birokrat di Kementerian Pertanian dan Dinas Pertanian di pemerintahan daerah, setelah sebuah kegiatan sensus lahan sawah dilakukan oleh Pemerintah Daerah Kabupaten Karawang. Pada 2013 Dinas Pertanian Kabupaten Karawang bekerja sama dengan Pusdatin Kementerian Pertanian menyelenggarakan sensus kepemilikan lahan sawah di daerahnya. Sensus kepemilikan sawah dengan alat bantu citra satelit dilengkapi dokumen bukti kepemilikan lahan dilakukan untuk memperbarui data luas baku sawah di wilayah tersebut. Data lengkap lokasi sawah dilakukan pendigitalan ke dalam peta dengan atribut nama dan alamat domisili pemilik dijadikan dasar penetapan LP2B di kabupaten tersebut.

Selanjutnya isu keempat yang berkembang adalah wacana perlu adanya persetujuan atau kesediaan pemilik lahan melalui sebuah surat pernyataan atau kontrak antara pemilik lahan dengan pemerintah diwakili kepala Dinas Pertanian setempat. Persepsi ini menjadi diskursus dalam setiap pembahasan LP2B dalam berbagai forum 
walaupun belum ada kajian khusus mengenai penerapan ketentuan ini di daerah.

Isu terakhir adalah wacana daerah berkewajiban untuk menetapkan LP2B seluas mungkin sebagai tanda keberpihakan pemerintah daerah tersebut dalam mewujudkan ketahanan dan kemandirian pangan. Persepsi ini berkembang menjadi ide protogonis pada forum-forum instansi lingkup pertanian tapi menjadi topik kontroversi pada forum lintas-instansi. Sumber daya lahan yang terbatas dihadapkan kepada kebutuhan penggunaan lahan oleh berbagai sektor yang terus berkembang dari waktu ke waktu seiring pertumbuhan penduduk menghasilkan dialog terus-menerus di antara harapan ideal dan realita rasional yang diwarnai egosektoral.

\section{Persepsi Mengenai Implementasi Perlindungan LP2B}

Pelaksanaan perlindungan LP2B telah diatur secara rinci dalam Peraturan Pemerintah Nomor 12 Tahun 2012 tentang Insentif Perlindungan LP2B. Namun demikian, wacana yang muncul ialah perencanaan lokasi pembangunan pertanian di daerah akan diutamakan atau bahkan akan dibatasi untuk kawasan LP2B. Penetapan luas LP2B menjadi perhatian khusus instansi sektor pertanian di daerah karena kekhawatiran bahwa alokasi kegiatan dari instansi pusat akan diproporsionalkan dengan luas LP2B yang ditetapkan di masing-masing daerah.

Persepsi yang timbul adalah semakin luas kawasan LP2B ditetapkan dalam suatu daerah, maka alokasi dana pembangunan pertanian di daerah tersebut semakin besar, dan begitu pula sebaliknya. Dalam sebuah forum lintas-instansi beberapa kali diungkapkan wacana bahwa Kementerian Pertanian akan menetapkan alokasi pupuk bersubsidi berdasarkan luas LP2B yang ditetapkan dalam Perda. Karena persepsi demikian, instansi sektor pertanian di daerah "berjuang keras" agar penetapan LP2B seluas mungkin atau bahkan kalau bisa seluruh lahan sawah yang ada ditetapkan menjadi LP2B. Semangat yang didasari ego-sektoral tersebut menjadi dilema tersendiri dalam perencanaan pembangunan, baik spasial (rencana tata ruang) maupun pembangunan sektoral (rencana pembangunan di sektor ekonomi, sosial, budaya, pendidikan, dan sektor lainnya).

Persepsi dan konsepsi mengenai perlindungan LP2B yang dibahas dari ketiga aspek tersebut di atas menggambarkan kompleks dan rumitnya perlindungan LP2B bahkan dimulai dari tataran konsep dan persepsi di kalangan internal instansi pemerintah. Pembahasan pada sub-bab berikutnya menguraikan analisis mengenai konsepsi dan persepsi penulis yang bertujuan memetakan situasi dan menguraikan kerumitan berdasarkan referensi ilmiah dan argumentasi hukum yang relevan.

\section{Perlindungan LP2B di Kabupaten Tasikmalaya}

Sejatinya UU LP2B merupakan amanat Undang-undang Nomor 26 Tahun 2007 tentang Penataan Ruang. Pada pasal 48 ayat 2 dinyatakan bahwa ketentuan lebih lanjut mengenai pelindungan terhadap kawasan lahan abadi pertanian pangan diatur dengan undang-undang. Sebagai pelaksanaan amanat undang-undang tersebut, melalui hak inisiatif Dewan Perwakilan Rakyat, UU LP2B disahkan pada 2009. Dengan latar belakang yuridis demikian, LP2B memiliki dua perspektif pembangunan, yaitu perspektif spasial karena berkaitan dengan ruang dan perspektif sektoral karena domain sektor pertanian.

Selanjutnya secara sektoral UU LP2B diterjemahkan oleh empat PP, yaitu: (1) PP No. 1 Tahun 2011 tentang Penetapan dan Alih Fungsi LP2B; (2) PP No. 12 Tahun 2012 tentang Insentif Perlindungan LP2B; (3) PP No. 25 Tahun 2012 tentang Sistem Informasi LP2B; dan (4) PP No. 30 Tahun 2012 tentang Pembiayaan Perlindungan LP2B. Dalam tataran operasional telah diterbitkan pula Permentan No. 07/Permentan/Ot.140/2/2012 tentang Pedoman Teknis Kriteria dan Persyaratan Kawasan, Lahan, dan Lahan Cadangan Pertanian Pangan Berkelanjutan.

Dalam implementasi teknis perencanaan pembangunan daerah, LP2B diatur dalam perencanaan spasial, yaitu rencana tata ruang secara umum (RTRW) maupun rinci (RDTR), dan perencanaan pembangunan sektoral jangka panjang (RPJPD), jangka menengah (RPJMD), maupun jangka pendek tahunan (RKPD), serta dalam Rencana Strategis (Renstra) sektor Pertanian. Di Kabupaten Tasikmalaya kombinasi pendekatan spasial dan sektoral tersebut diuraikan pada sub-bab berikutnya mengenai perlindungan LP2B di Kabupaten Tasikmalaya.

Secara kronologis, perlindungan LP2B di Kabupaten Tasikmalaya dimulai pada 2014 dengan kegiatan perencanaan berupa pemetaan lahan sawah. Teridentifikasi luas lahan sawah hasil pemetaan pada saat itu seluas $45.153 \mathrm{Ha}$ yang terletak di 47.542 blok. Berdasarkan hasil kajian, lahan sawah yang memenuhi kriteria untuk ditetapkan menjadi LP2B menurut Permentan No. 07 Tahun 2012 adalah seluas $19.699 \mathrm{Ha}$ yang tersebar di 1.778 blok. 
Hasil perencanaan dan kajian yang dilakukan oleh Dinas Pertanian itu kemudian pada Februari 2015 diserahkan sebagai usulan teknis kepada instansi yang mengelola penataan ruang dalam hal ini Bappeda dan Dinas Tata Ruang untuk kemudian ditetapkan dalam perda tata ruang. Peta sawah yang memuat rencana LP2B juga diserahkan kepada seluruh camat dan koordinator penyuluh kecamatan sebagai referensi dalam perencanaan dan pengambilan keputusan sesuai dengan kewenangannya.

Pada 2015 dilaksanakan penyusunan Naskah Akademis (NA) dan rancangan perda LP2B untuk mengkaji apakah diperlukan ataukah tidak perda LP2B di Kabupaten Tasikmalaya. Secara yuridis, UU LP2B dan peraturan turunannya tidak mewajibkan kabupaten/kota untuk menetapkan perda LP2B. Akan tetapi, peraturan perundang-undangan secara eksplisit mewajibkan kabupaten/kota untuk menetapkan LP2B dalam rencana tata ruang.

Secara sektoral, Naskah Akademis yang disusun oleh tim ahli multidisiplin ilmu menyimpulkan bahwa Kabupaten Tasikmalaya perlu menetapkan perda tentang LP2B untuk mengatur norma hukum dan upaya sektoral dalam mewujudkan rencana pola ruang LP2B dalam rencana tata ruang. Pada akhir 2015 Dinas Pertanian mengusulkan LP2B menjadi agenda pembahasan dalam Program Legislasi Daerah (Prolegda) Tahun 2016. Sebagai diferensiasi dan upaya mencegah tumpang tindih aturan, maka perda LP2B "hanya" mengatur Bagaimana melindungi LP2B. Adapun pengaturan Di mana lokasi dan Berapa Luas LP2B di Kabupaten Tasikmalaya diatur dalam perda tata ruang (Perda RTRW dan Perda RDTR).

Secara pararel, pengaturan LP2B dalam perspektif sektoral dan spasial berproses sesuai dengan kewenangannya. Pada 2015 dilaksanakan pula penyusunan materi teknis RDTR di tujuh kawasan perkotaan dan dua kawasan strategis di Kabupaten Tasikmalaya oleh Dinas Tata Ruang. Tujuh kawasan perkotaan itu adalah perkotaan Singaparna sebagai kawasan ibu kota, perkotaan Ciawi, Rajapolah, Manonjaya, Taraju, Karangnunggal, dan Cibalong. Selain itu, disusun pula materi teknis Rencana Kawasan Strategis Kabupaten dan rencana tata ruang koridor jalan Ciawi-Singaparna. Dalam penyusunan materi teknis tersebut rencana LP2B yang telah dipetakan oleh Dinas Pertanian pada 2014 diusulkan untuk dimasukkan ke dalam peta rencana tata ruang untuk kemudian dalam proses selanjutnya ditetapkan dalam perda tentang RDTR di masing-masing perkotaan dan kawasan.

Pada 2016 Ranperda LP2B dibahas oleh DPRD dengan melakukan serangkaian sidang komisi, rapat pokja, kunjungan kerja ke Dinas Pertanian Provinsi Jawa Barat dan Kementerian Pertanian, serta studi banding ke Kabupaten Sukabumi. Dalam Sidang Paripurna DPRD pada November 2016 ditetapkan Peraturan Daerah Kabupaten Tasikmalaya Nomor 4 Tahun 2016 tentang Perlindungan Lahan Pertanian Pangan Berkelanjutan (selanjutnya disebut Perda LP2B).

Pada 2017 Bappeda melakukan peninjauan kembali (review) Perda Nomor 2 tahun 2012 tentang RTRW Kabupaten Tasikmalaya Tahun 20112031 (selanjutnya disebut Perda RTRW). Salah satu materi yang ditinjau kembali adalah penetapan Kawasan Lahan Pertanian Pangan Berkelanjutan (KP2B). Sesuai dengan peraturan perundangundangan, Perda RTRW menetapkan KP2B dan Perda RDTR menetapkan LP2B. Pada perjalanannya, terjadi tarik ulur kepentingan di antara stakeholder dalam penentuan luasan KP2B. Hampir semua isu yang dibahas pada sub-bab permasalahan terjadi pada proses review Perda RTRW ini. Walaupun telah ada angka sementara luas KP2B, yaitu sebesar $47.439 \mathrm{Ha}$, sebagai hasil kompromi dan diskusi yang panjang di antara stakeholder, sampai artikel ini ditulis belum ada keputusan final tentang luas kawasan KP2B yang akan ditetapkan.

Secara pararel pada 2017 melalui proses legislasi yang sama dengan Perda LP2B, ditetapkan Peraturan Daerah Nomor 9 Tahun 2017 tentang Rencana Detail Tata Ruang dan Peraturan Zonasi Perkotaan Singaparna Kabupaten Tasikmalaya Tahun 2017-2037 (selanjutnya disebut Perda RDTR Singaparna). Dalam pasal 29 Perda RDTR Singaparna ditetapkan zona tanaman pangan LP2B seluas 923,84 $\mathrm{Ha}$ yang tersebar di 16 blok. Dibandingkan dengan luas wilayah perkotaan Singaparna sebesar 4.138,74 Ha, proporsi LP2B sebesar 22,32 \% mengindikasikan bahwa arah pembangunan ruang di perkotaan Singaparna bersifat konservatif. Hal ini sesuai dengan tujuan penataan ruang perkotaan Singaparna yang tercantum dalam pasal 3, yaitu untuk "Mewujudkan Perkotaan Singaparna sebagai pusat pemerintahan kabupaten dan kawasan agropolitan yang berkelanjutan". Dengan kata lain, Perda RDTR mengamanatkan bahwa pada 2037 di wilayah perkotaan Singaparna terdapat lahan sawah minimal $22,32 \%$ dari total wilayah ibu kota. 
Sebagai insentif atas terbitnya Perda LP2B, pada 2017 Kementerian Pertanian mengalokasikan anggaran melalui tugas pembantuan berupa kegiatan pra-sertifikasi untuk calon lahan LP2B sebanyak 200 persil. Kegiatan pendataan subjek dan objek tanah untuk disertifikasi ini hasilnya diserahkan kepada BPN Kabupaten Tasikmalaya untuk selanjutnya BPN mengalokasikan anggaran untuk sertifikasi lahan yang telah memenuhi kriteria pada 2018.

Pada 2018 dilakukan sosialisasi Perda RDTR Sigaparna sebagai langkah awal penerapan perda. Proses legislasi RDTR wilayah perkotaan lainnya masih berjalan dengan berbagai dinamika dan kendala spesifik tersendiri. Pada tahun yang sama dilakukan kegiatan penyusunan roadmap perlindungan LP2B oleh Dinas Pertanian sebagai peta jalan perlindungan LP2B sebagaimana diatur dalam perda.

Pada 2019 Dinas Pertanian melaksanakan kegiatan identifikasi pemilik lahan LP2B di perkotaan Singaparna yang ditetapkan dalam Perda RDTR. Kegiatan ini bertujuan untuk mengidentifikasi objek dan subjek (pemilik lahan by name by address) LP2B dengan metode sensus. Kegiatan ini sebagai bagian upaya sosialisasi Perda RDTR Singaparna sekaligus menyerap aspirasi pemilik LP2B mengenai jenis insentif apa yang mereka paling kehendaki atas ditetapkannya lahan mereka menjadi LP2B.

\section{Menjawab Mispersepsi dan Miskonsepsi Stakeholder}

Kronologi upaya perlindungan LP2B di Kabupaten Tasikmalaya yang diuraikan di atas mencatat diskursus, pro-kontra, perbedaan persepsi dan perbedaan konsepsi yang menjadi permasalahan dalam artikel ini. Permasalahan ini tidak serta-merta berakhir ketika Perda LP2B dan perda lainnya yang berkaitan ditetapkan. Proses dan tahapan perlindungan LP2B di provinsi Jawa Barat dan daerah lain yang berbeda dengan di Kabupaten Tasikmalaya, disertai perbedaan paradigma hukum yang digunakan antar-daerah dan antar-instansi menyebabkan topik permasalahan dalam artikel ini muncul kembali secara berulang di berbagai forum. Meskipun demikian, catatan perjalanan panjang perlindungan LP2B di Kabupaten Tasikmalaya dapat disintesis menjadi jawaban terhadap topik permasalahan sebagaimana diuraikan pada sub-bab selanjutnya.

\section{Menjawab Mispersepsi Mengenai Kepemilikan Lahan}

Persepsi stakeholder yang menganggap perlindungan LP2B hanya bisa efektif bila LP2B dimiliki atau dibebaskan oleh pemerintah selain tidak mungkin direalisasikan secara nasional juga dinilai kehilangan arah atau menyesatkan (misleading) karena tiga alasan.

Alasan pertama adalah persepsi tersebut menyelisihi esensi pemerintah (sektor publik) yang berperan sebagai regulator ekonomi negara yang berorientasi manfaat sosial (social benefit), bukan sebagai aktor ekonomi (sektor privat/swasta) yang berorientasi laba (corporate profit). Dalam konteks ini, kecuali untuk media diseminasi teknologi dan pilot project dalam skala laboratorium, tidak relevan dan tidak efisien apabila pemerintah secara langsung membeli lahan untuk melakukan usaha tani demi memastikan produksi pangan.

Argumentasi kedua adalah sebagai regulator pemerintah melihat sektor pertanian dalam perspektif luas sebagai salah satu sektor ekonomi di antara sektor-sektor lainnya yang harus diperhatikan secara adil dan proporsional. Sebagai salah satu mata pencaharian masyarakat, pertanian sebagaimana mata pencaharian lainnya seperti perdagangan, industri, dan jasa dalam aktivitas ekonominya berinteraksi satu sama lain dalam mekanisme pasar. Pemerintah berperan untuk memastikan bahwa interaksi antar-sektor tersebut dalam kondisi keseimbangan umum (general equilibrium) yang berkeadilan. Intervensi pemerintah dalam bentuk kebijakan subsidi, penetapan tarif (baik tarif atas atau tarif bawah), maupun pajak yang dikenakan kepada salah satu sektor ekonomi dilakukan untuk merespons kegagalan pasar (market failure) atau bertujuan untuk menjalankan asas keadilan. Pemilikan lahan pertanian oleh negara untuk kepentingan produksi pangan sebagai salah satu komoditas ekonomi menyalahi asas keadilan dan berpotensi menimbulkan ketidakseimbangan ekonomi.

Alasan terakhir adalah bahwa justru karena lahan pertanian berstatus milik perorangan/masyarakat, maka kehadiran negara dibutuhkan untuk mengatur pengendalian penggunaannya. Sebagaimana esensi peraturan perundang-undangan lainnya yang mengatur warga negara termasuk di dalamnya hak kepemilikan (property rights), negara memiliki hak konstitusi untuk mengaturnya demi kepentingan atau manfaat bersama dalam jangka panjang (long run). Adagium 
"sawab dewek kumaha dewek" yang merepresentasikan hak asasi warga negara dalam berkehendak dapat diharmonikan dengan kehendak negara melalui mekanisme insentif dan disinsentif.

Dengan tiga argumen di atas, persepsi bahwa pemerintah atau negara perlu membebaskan lahan sawah agar perlindungan LP2B dapat berjalan secara efektif adalah persepsi yang keliru (mispersepsi) atau pendapat yang tidak benar (miskonsepsi).

\section{Menjawab Mispersepsi mengenai Proses Penetapan LP2B}

Sebagaimana diuraikan dalam sub-bab permasalahan, ada lima isu yang berkaitan dengan aspek proses penetapan LP2B. Kelima isu itu ialah: (1) kekaburan stakeholder mengenai penetapan LP2B apakah (cukup) ditetapkan dalam Perda Tata Ruang ataukah (perlu juga) ditetapkan dalam Perda LP2B secara khusus; (2) wacana penentuan luasan LP2B kabupaten/kota diatur oleh pemerintah provinsi; (3) wacana penetapan lokasi LP2B perlu didahului oleh identifikasi pemilik lahan secara lengkap (by name by address); (4) wacana penetapan LP2B perlu dengan persetujuan pemilik lahan; dan (5) wacana pemerintah daerah harus menetapkan LP2B seluas mungkin sebagai simbol keberpihakan kepada ketahanan dan kedaulatan pangan. Uraian selanjutnya akan menjelaskan narasi bahwa ada kekeliruan atau kelemahan argumentasi dari kelima persepsi tersebut.

Dalam catatan penulis, terdapat perbedaan perspektif dalam menyusun Perda LP2B. Sebagian besar daerah menjadikan LP2B sebagai perda spasial. Dengan perspektif demikian, Perda LP2B mengatur atau menetapkan lokasi LP2B beserta luasannya dilengkapi dengan peta LP2B sebagai lampiran yang tidak terpisahkan dari pasal-pasal tekstual perda. Dalam catatan penulis yang terbatas daerah yang memiliki Perda LP2B, dengan perspektif ini di antaranya adalah Kabupaten Sukabumi (Jawa Barat) dan Kabupaten Temanggung (Jawa Tengah).

Sebagian daerah lainnya memandang Perda LP2B sebagai perda sektoral. Dalam perspektif ini, Perda LP2B hanya mengatur norma hukum LP2B tanpa menetapkan lokasi, luasan, dan tanpa lampiran peta. Perda LP2B dijadikan dasar hukum dalam menentukan strategi, kebijakan, program dan kegiatan sektor pertanian dan sektor lain yang terkait dalam upaya perlindungan LP2B. Kabupaten Tasikmalaya adalah salah satu daerah yang memiliki perspektif ini dengan pengaturan spasial LP2B diatur dalam perda mengenai tata ruang sebagaimana dijelaskan secara kronologis pada sub-bab sebelumnya.

Dengan asumsi bahwa sebuah produk hukum berupa perda telah dikaji secara mendalam oleh ahli dari multidisiplin ilmu termasuk ahli ilmu hukum, maka kedua perspektif itu bisa berterima. Namun demikian, kedua perspektif tersebut memiliki kelebihan dan kelemahan masing- masing.

Perda LP2B berperspektif spasial berpotensi bertumpang tindih dengan perda tata ruang. Sebagai contoh di Kabupaten Temanggung, Perda Nomor 2/2014 tentang LP2B tidak sesuai dengan ketentuan Perda Nomor 1/2012 tentang RTRW Kabupaten Temanggung. Seperti diberitakan oleh media masa, pada Februari 2015, Pansus DPRD menemukan tiga desa di Kecamatan Kranggan, yakni Nguwet, Badran, dan Bengkal, ditetapkan sebagai kawasan pertanian pangan berkelanjutan pada Perda LP2B. Padahal, seperti diberitakan laman Suara Merdeka, menurut Perda RTRW, daerah setempat adalah kawasan industri. Muryono (2016) mengalkulasi bahwa masih ada ketidaksesuaian sebesar 10,55\% antara RTRW dan LP2B di Kabupaten Temanggung. Karena temuan ini, Kabupaten Temanggung melakukan revisi dengan menerbitkan Perda No. 4 Tahun 2017 tentang perubahan Perda No. 2/2014 tentang LP2B.

Di sisi yang lain, Perda LP2B berperspektif sektoral terbebas dari kemungkinan tumpang tindih dengan perda tata ruang karena perda tata ruang yang berwenang mengatur dan menetapkan LP2B sebagai salah satu rencana pola ruang. Kelemahannya adalah Perda LP2B tanpa menetapkan peta berkesan tidak beresensi. Dalam proses penyusunan Perda LP2B Kabupaten Tasikmalaya, di dalam forum konsultasi dengan instansi lingkup pertanian, stakeholder banyak yang beropini bahwa percuma apabila Perda LP2B hanya berisi teks pasal-pasal tanpa dilengkapi dengan peta. Pada umumnya stakebolder memiliki persepsi bahwa Perda LP2B adalah perda spasial sehingga sampai saat ini banyak stakebolder yang bertanya atau mengonfirmasi kepada penulis: "Berapa hektar luas LP2B di Kabupaten Tasikmalaya berdasarkan Perda LP2B?”

Isu selanjutnya adalah tentang peranan pemerintah provinsi dalam penentuan LP2B di kabupaten/kota. Mispersepsi ini bisa dijawab bahwa dalam ketentuan peraturan perundang-undangan dijelaskan bahwa kawasan pertanian pangan berkelanjutan provinsi adalah hamparan lahan pangan lintas kabupaten/kota. Adapun kawasan pertanian pangan berkelanjutan nasional adalah hamparan lahan lintas provinsi. 
Selanjutnya mengenai perhitungan skala ekonomi yang menjadi prasyarat suatu lahan ditetapkan sebagai LP2B, hal ini telah tuntas dikalkulasi dalam Peraturan Menteri Pertanian Nomor 07/Permentan/Ot.140/2/2012 tentang Pedoman Teknis Kriteria dan Persyaratan Kawasan, Lahan, dan Lahan Cadangan Pertanian Pangan Berkelanjutan. Dalam Permentan tersebut telah ditentukan bahwa luas LP2B paling sedikit $5 \mathrm{Ha}$ hamparan, sedangkan KP2B paling sedikit hamparan seluas $20 \mathrm{Ha}$.

Permasalahan ketiga adalah tentang penetapan LP2B didahului oleh pendataan pemilik lengkap (by name by address) yang berkaitan dengan permasalahan keempat, yaitu penetapan LP2B harus melalui persetujuan pemilik lahan ditandai dengan surat pernyataan atau kontrak. Kedua persepsi ini menambah kesulitan sendiri dalam perencanaan LP2B. Argumen yang digunakan untuk menjawab dua persepsi ini adalah perencanaan LP2B harus diposisikan sama dan setara dengan pola ruang lain. Dalam perencanaan ruang, LP2B merupakan turunan dalam hierarki kawasan budidaya pertanian tanaman pangan.

Penetapan suatu kawasan sebagai rencana pola ruang tertentu menggunakan pertimbangan teknis sebagai justifikasi. Misalnya kawasan lindung setempat ditentukan pada kawasan sempadan sungai, sempadan laut, kawasan rawan gerakan tanah, kawasan rawan gunung api, kawasan resapan air, dan kawasan hutan. Contoh lain suatu kawasan budidaya peruntukan permukiman atau industri menggunakan pertimbangan teknis yang relevan sebagai justifikasi bahwa kawasan tersebut cocok untuk permukiman atau pengembangan industri. Dengan menggunakan pertimbangan teknis itu, pemerintah berhak menentukan suatu kawasan tertentu sebagai kawasan lindung atau kawasan budidaya tanpa memperhatikan siapa pemilik lahan tersebut.

Dengan kata lain, perencanaan tata ruang merupakan perencanaan teknokratis, bukan perencanaan partisipatif. Penetapan LP2B dalam perda tata ruang atas dasar perencanaan teknis Dinas Pertanian berdasarkan ketentuan Peraturan Menteri Pertanian No. 07/Permentan/Ot.140/2/2012 tentang Pedoman Teknis Kriteria dan Persyaratan Kawasan, Lahan, dan Lahan Cadangan Pertanian Pangan Berkelanjutan. Adapun Pendataan pemilik lahan lengkap (by name by address) merupakan langkah awal dari upaya perwujudan ruang setelah LP2B ditetapkan untuk kepentingan pemberian insentif bagi pemilik lahan.
Ketika insentif diberikan kepada pemilik lahan, pemerintah dapat memberikan prasyarat berupa kesediaan pemilik lahan untuk tidak mengalihfungsikan lahan pertaniannya dalam kurun waktu tertentu. Apabila pemilik lahan menyalahi kesepakatan, maka pemerintah berhak menarik kembali insentif yang diberikan dan memberikan disinsentif tambahan sebagai konsekuensi sesuai dengan peraturan perundang-undangan. Dalam konteks inilah Perda LP2B diperlukan keberadaannya. Pemerintah daerah memerlukan payung hukum yang memadai untuk melaksanakan fungsi pemberian insentif dan disinsentif LP2B. Selain itu, Perda LP2B dijadikan sebagai penerjemahan yang lebih rinci dari UU LP2B beserta turunannya disesuaikan dengan kearifan lokal yang ada untuk menjadi panduan dalam bagaimana melindungi LP2B, bukan (hanya sekadar) di mana dan berapa luas LP2B.

Isu terakhir mengenai proses penetapan LP2B yang menjadi permasalahan dalam artikel ini adalah persepsi bahwa pemerintah daerah perlu menetapkan seluas mungkin LP2B sebagai simbol keberpihakan terhadap ketahanan dan kemandirian pangan. Persepsi ini sepintas sangat ideal dan heroik tapi berpotensi menjadi blunder bagi pemerintah sendiri. Penerbitan Perda LP2B atau penetapan suatu kawasan LP2B bukan puncak atau ujung dari pembangunan pertanian berkelanjutan. Dengan ditetapkannya Perda LP2B tidak berarti serta-merta alih fungsi lahan bisa dikendalikan. Akan tetapi, penetapan LP2B adalah awal dari segala upaya pengendalian alih fungsi lahan karena penetapan LP2B dalam perda tata ruang disebut sebagai Rencana Pola Ruang LP2B (perlu digarisbawahi: bermakna baru sebagai rencana). Rencana pola ruang dilanjutkan dengan upaya perwujudan ruang.

Ketika suatu kawasan ditetapkan sebagai LP2B, hal pertama yang muncul di benak aparat pemerintah adalah bukan sebuah pernyataan: "kawasan ini tidak boleh beralih fungsi, apabila beralih fungsi melanggar hukum”. Akan tetapi, yang muncul seharusnya sebuah pertanyaan: "Insentif apa yang perlu diberikan agar kawasan ini tidak beralih fungsi?" Pertanyaan itu kemudian diterjemahkan kedalam Renstra, RPJMD, dan RKPD. Ketika berbicara anggaran, ini erat kaitannya dengan kemampuan pemerintah daerah yang tercermin dalam APBD. Sebagai analogi apabila di Kabupaten Tasikmalaya ditetapkan LP2B seluas $47.439 \mathrm{Ha}$, untuk memberikan insentif berupa perbaikan jaringan irigasi saja dikalkulasi tidak selesai dalam lima tahun anggaran. Dengan kata lain, konsepsi 
mengenai pemerintah daerah harus menetapkan LP2B seluas mungkin adalah suatu miskonsepsi dalam tataran implementasi.

\section{Menjawab Mispersepsi Mengenai Implementasi Perlindungan LP2B}

Pada tataran implementasi permasalahan muncul ketika LP2B dijadikan dasar dalam perencanaan pembangunan sektor pertanian. Di antara konsepsi yang muncul di kalangan stakeholder adalah wacana pembangunan pertanian, termasuk subsidi pertanian, akan memprioritaskan atau dibatasi untuk LP2B. Konsep pembangunan seperti ini misleading atau tersesat karena jebakan status atau terminologi spasial. Fakta di lapangan adalah banyak lahan sawah yang berstatus sebagai kawasan lindung karena terletak dalam kawasan sempadan sungai, sempadan pantai, kawasan rawan bencana gunung api, kawasan rawan pergerakan tanah bahkan banyak sawah yang terletak pada kawasan hutan. Dalam konteks ini sebenarnya banyak lahan pertanian yang terlindungi secara hukum dari alih fungsi (tidak boleh beralih fungsi) karena secara spasial berada dalam kawasan lindung. Bahkan secara yuridis perlindungan hukumnya lebih kuat daripada kawasan berstatus LP2B karena berada di kawasan budidaya. Dalam peraturan alih fungsi, LP2B masih dibolehkan beralih fungsi untuk kepentingan umum dengan disinsentif tertentu. Adapun kawasan lindung mutlak terlarang untuk beralih fungsi. Dengan penjelasan ini, stakeholder dari instansi lingkup pertanian tidak perlu "berjuang dengan keras" agar penetapan LP2B seluas mungkin di dalam perda.

Selain itu, tidak sedikit kawasan yang berstatus sebagai kawasan permukiman, perdagangan, industri, dan kawasan budidaya lainnya pada faktanya di lapangan adalah lahan sawah. Hal ini bisa terjadi karena peta rencana tata ruang adalah rencana berperspektif 20 tahun ke depan, bukan peta penggunaan lahan eksisting. Dengan demikian, perencanaan pembangunan pertanian pangan yang berinterval 4 bulanan (untuk tanaman padi) tidak relevan menggunakan peta tata ruang yang berinterval 20 tahunan. Perencanaan pembangunan pertanian lebih relevan untuk tetap berdasarkan kepada luas baku lahan dalam statistik lahan yang dirilis BPS setiap tahun.

Peta penggunaan lahan eksisting dan statistik lahan tahunan BPS dikombinasikan dengan peta rencana tata ruang dapat digunakan stakebolder lingkup pertanian dalam memprediksi laju alih fungsi yang selanjutnya untuk proyeksi perubahan produksi pangan 20 tahun ke depan. Selanjutnya, proyeksi produksi pangan tersebut dapat dijadikan dasar perencanaan program perluasan areal atau cetak sawah baru. Adapun penetapan LP2B merupakan instrumen bagi pemerintah dalam perizinan pemanfaatan ruang, bukan instrumen dalam perencanaan pembangunan pertanian. Dengan konstruksi berpikir demikian, maka diskursus, tarik ulur kepentingan, perdebatan dalam penetapan LP2B karena miskonsepsi dan mispersepsi dapat diminimalkan.

\section{KESIMPULAN}

Dari pembahasan di atas dapat ditarik benang merah bahwa dinamika komunikasi dalam sektor publik atau pemerintahan kerap diwarnai dengan mispersepsi dan miskonsepsi. Hal ini disebabkan perbedaan kepentingan atau ego sektoral. Studi kasus dalam proses penyusunan Peraturan Daerah Kabupaten Tasikmalaya tentang Perlindungan Lahan Pertanian Berkelanjutan menunjukkan bahwa mispersepsi dan miskonsepsi itu tidak serta-merta berakhir seketika telah tercapai konsensus penetapan peraturan daerah tersebut, namun terus berlanjut dalam tataran implementasi dan koordinasi lintas-instansi. Penerapan sebuah peraturan daerah menjadi lebih sulit bahkan dimulai pada tataran konsep dan persepsi birokratnya. Meskipun demikian, proses penyusunan perda tersebut dapat disintesis menjadi konsepsi yang argumentatif untuk menjawab atau meluruskan mispersepsi dan miskonsepsi yang ada di kalangan stakebolder.

Berdasarkan sintesis dari catatan perjalanan penyusunan Perda LP2B di Kabupaten Tasikmalaya, rekomendasi yang dapat disarankan adalah sebagai berikut:

1. Dalam upaya perlindungan LP2B, semua pihak direkomendasikan untuk mengupayakannya dengan penuh optimisme. Lahan pertanian pangan milik perorangan sebagai bagian dari hak asasi kepemilikan (property rights) yang diekspresikan dalam adagium Sunda "sawab ewek kumaba dewek" masih bisa diintervensi dengan insentif dan disinsentif yang menarik dan konsisten dengan instrumen peraturan daerah yang jelas.

2.Proses penetapan LP2B direkomendasikan untuk disederhanakan dengan perspektif pendekatan teknokratis sebagaimana penetapan rencana pola ruang lain dalam perencanaan tata ruang. Pendekatan partisipatif direkomendasikan dalam tahap upaya perwujudan ruang karena LP2B adalah sebuah bagian dari rencana tata ruang yang perwujudannya dilaksanakan kemudian.

3. Peta LP2B direkomendasikan untuk digunakan 
sebagai instrumen pemerintah dalam izin pemanfaatan ruang. Akan tetapi, tidak direkomendasikan menjadi instrumen perencanaan pembangunan pertanian secara umum. Perencanaan pembangunan pertanian direkomendasikan untuk tetap menggunakan instrumen peta penggunaan lahan eksisting berdasarkan sensus luas baku lahan yang dirilis BPS setiap tahun. Tidak sedikit lahan pertanian pangan tidak ditetapkan sebagai LP2B karena terletak pada kawasan lindung. Dalam konteks ini, lahan pertanian pangan tersebut telah terlindungi dari alih fungsi dengan sendirinya tanpa harus ditetapkan sebagai LP2B.

\section{DAFTAR PUSTAKA}

Djajadiningrat, S.T. (1992). Konsep Pembangunan Berkelanjutan dalam Membangun Tanpa Merusak Lingkungan. Jakarta: Kantor Menteri Negara Lingkungan Hidup

Kabupaten Tasikmalaya. (2011). Peraturan Daerab Kabupaten Tasikmalaya Nomor 2 Tabun 2012 tentang Rencana Tata Ruang Wilayah Kabupaten Tasikmalaya Tabun 2011-2031. Singaparna: Lembaran Daerah Tahun 2012 Nomor 2. Sekretariat Daerah Kabupaten Tasikmalaya

Kabupaten Tasikmalaya. (2016). Peraturan Daerab Kabupaten Tasikmalaya Nomor 4 Tabun 2016 tentang Laban Pertanian Pangan Berkelanjutan. Lembaran Daerah Tahun 2016 Nomor 4 NOREG Peraturan Daerah Kabupaten Tasikmalaya Nomor 4/192/2016. Singaparna: Sekretariat Daerah Kabupaten Tasikmalaya

Kabupaten Tasikmalaya. (2017). Peraturan Daerah Nomor 9 Tabun 2017 tentang Rencana Detail Tata Ruang dan Peraturan Zonasi Perkotaan Singaparna Kabupaten Tasikmalaya Tahun 2017-2037. Lembaran Daerah Tahun 2017 Nomor 9 NOREG Peraturan Daerah Kabupaten Tasikmalaya Nomor 9/346/2017. Singaparna: Sekretariat Daerah Kabupaten Tasikmalaya

Muryono, Slamet. (2016). “Kajian Upaya Pengendalian Tanah di Kabupaten Temanggung Jawa Tengah”. Jurnal Agraria dan Pertanahan, 1 (2), hlm. 84-101

Pearce, D. \& Warford, J. (1993). World without End: Economics, Environment and Sustainable Development. Oxford: Oxford University Press

Provinsi Jawa Barat. (2010). Peraturan Daerab Provinsi Jawa Barat Nomor 27 Tabun 2010 Tentang Perlindungan Laban Pertanian Pangan Berkelanjutan. Lembaran Daerah Tahun 2010 Nomor 27 Seri E. Bandung: Sekretariat Daerah Provinsi Jawa Barat

Pusat Bahasa. Kamus Besar Bahasa Indonesia (daring). https://kbbi.kemdikbud.go.id

Republik Indonesia. (2007). Undang-Undang Republik Indonesia Nomor 26 Tabun 2007 tentang Penataan Ruang. Lembaran Negara Republik Indonesia Tahun 2007 Nomor 68, Tambahan Lembaran Negara Republik Indonesia Nomor 4725. Jakarta: Sekretariat Negara

Republik Indonesia. (2009). Undang-Undang Republik Indonesian Nomor 41 Tabun 2009 Tentang Perlindungan Laban Pertanian Pangan Berkelanjutan. Lembaran Negara Republik Indonesia Tahun 2009 Nomor 149, Tambahan Lembaran Negara Republik Indonesia Nomor 5068. Jakarta: Sekretariat Negara

Republik Indonesia. (2011). Peraturan Pemerintah Nomor 1 Tabun 2011 tentang Penetapan dan Alib Fungsi Laban Pertanian Pangan Berkelanjutan. Lembaran Negara Tahun 2011 Nomor 2, Tambahan Lembaran Negara Nomor 5185. Jakarta: Sekretariat Negara

Republik Indonesia. (2012). Peraturan Pemerintah Republik Indonesia Nomor 12 Tabun 2012 Tentang Insentif Perlindungan Laban Pertanian Pangan Berkelanjutan. Lembaran Negara Republik Indonesia Tahun 2012 Nomor 19, Tambahan Lembaran Negara Republik Indonesia Nomor 5279. Jakarta: Sekretariat Negara

Republik Indonesia. (2012). Peraturan Pemerintab Republik Indonesia Nomor 25 Tabun 2012 Tentang Sistem Informasi Lahan Pertanian Pangan Berkelanjutan. Lembaran Negara Republik Indonesia Tahun 2012 Nomor 46, Tambahan Lembaran Negara Republik Indonesia Nomor 5283. Jakarta: Sekretariat Negara

Republik Indonesia. (2012). Peraturan Pemerintah Republik Indonesia Nomor 30 Tabun 2012 Tentang Pembiayaan Perlindungan Laban Pertanian Pangan Berkelanjutan. Lembaran Negara Republik Indonesia Tahun 2012 Nomor 55, Tambahan Lembaran Negara Republik Indonesia Nomor 5288. Jakarta: Sekretariat Negara

Republik Indonesia. (2012). Peraturan Menteri Pertanian Nomor 07/Permentan/Ot.140/2/2012 Tentang Pedoman Teknis Kriteria dan Persyaratan Kawasan, Laban, dan Laban Cadangan Pertanian Pangan Berkelanjutan. Berita Negara Tahun 2012 Nomor. Jakarta: Sekretariat Kementerian Pertanian 